Ng, C. S., J. R. Duncan, and N. Koper. 2018. Who's "hooting"? Motivations and scientific attitudes of Manitoban citizen science owl surveyors. Avian Conservation and Ecology 13(2):9. https://doi.org/10.5751/ACE-01265-130209

Copyright (C) 2018 by the author(s). Published here under license by the Resilience Alliance.

Methodology

\title{
Who's "hooting"? Motivations and scientific attitudes of Manitoban citizen science owl surveyors
}

\author{
Christoph S. $\mathrm{Ng}^{1}$, James R. Duncan ${ }^{2,3}$ and Nicola Koper ${ }^{1}$ \\ ${ }^{1}$ University of Manitoba, ${ }^{2}$ Wildlife and Fisheries Branch, Manitoba Sustainable Development, ${ }^{3}$ Discover Owls
}

\begin{abstract}
Citizen science is gaining popularity as a means for all persons to participate in and contribute to scientific projects, and can increase our understanding of avian conservation and ecology by facilitating the collection of more data. Understanding the type of person who participates in citizen science projects, including their motivations, behaviors, and gains, allows researchers to better recruit and retain participants and to design enjoyable and educational projects with direct and indirect benefits to conservation and science. We surveyed participants of the Manitoba Nocturnal Owl Survey, an ongoing 25-year-old citizen science project, to evaluate how and why people participated and to determine their relationship with science and ecology. The interpersonal dimensions of surveying was important at all stages of participation, affecting recruitment, participation, and reasons for leaving. Being in nature and encountering wildlife was often cited as the most important aspect of the actual surveying experience, though many respondents also reported they enjoyed experiencing nature socially. Educational opportunity was rarely cited as a motivation, although gaining knowledge was the most common reported benefit. Respondents were highly educated, and concerned about a variety of environmental and conservation issues. The majority of respondents had participated in multiple citizen science projects. Marketing citizen science projects as social learning opportunities embedded in nature may help attract and retain more volunteers, ensuring long-term sustainability of programs while engaging new participants in activities that increase their ecological knowledge and awareness.
\end{abstract}

\section{Qui imite les hiboux? Motivations et attitudes scientifiques des participants manitobains aux inventaires de hiboux}

RÉSUMÉ. La science citoyenne gagne en popularité en raison du fait que tous peuvent participer et contribuer à des programmes scientifiques, et qu'elle peut améliorer notre compréhension de la conservation et de l'écologie des oiseaux en facilitant la collecte de plus de données. La capacité de cerner le type de personne qui participe aux programmes scientifiques citoyens, dont sa motivation, ses comportements et ce qu'elle en retire, permet aux chercheurs de mieux recruter et retenir les participants et de concevoir des projets intéressants et éducatifs présentant des bénéfices directs et indirects pour la conservation et la science. Nous avons sondé les participants à l'inventaire des hiboux nocturnes du Manitoba, un programme de science citoyenne mis en place il y a 25 ans, pour évaluer de quelle façon et pourquoi les personnes ont participé et pour déterminer leurs relations avec la science et l'écologie. Les dimensions interpersonnelles de l'acte d'inventaire étaient importantes à tous les stades de participation, tant le recrutement, la participation que les raisons d'un abandon. Le fait d'être dans la nature et de voir des animaux était souvent la raison citée comme l'aspect le plus important de l'expérience d'inventaire elle-même, bien que de nombreux répondants ont aussi rapporté qu'ils aimaient cette activité pour son côté social. L'occasion de s'éduquer a rarement été citée en tant que motivation pour les participants, mais l'acquisition de connaissances a été le bénéfice qu'ils ont le plus souvent rapporté. Les répondants étaient très éduqués et se sentaient concernés par une variété d'enjeux environnementaux et de conservation. La majorité des sondés avaient participé à de multiples programmes de science citoyenne. La promotion des programmes de science citoyenne en tant qu'occasions sociales d'apprentissage en nature peut aider à attirer et à retenir plus de bénévoles, assurant la pérennité des programmes tout en engageant de nouveaux participants dans des activités qui augmentent leurs connaissances en écologie et leur sensibilisation.

Key Words: amateur naturalists; citizen science; motivations; participation; volunteers

\section{INTRODUCTION}

Public participation in scientific research has grown in popularity since the Cornell Lab of Ornithology began marketing this practise as "citizen science" in 1995 (Bonney et al. 2009, 2016). Several categories of citizen science projects exist based on the degree of participation by volunteers (reviewed in Shirk et al. 2012, Bonney et al. 2016), but arguably the most common in ecology is the contributory-style project. Contributory projects are typically designed and organized by researchers to answer a specific scientific question. Researchers recruit and train citizen scientists to collect the data, which is returned to them for analysis. The use of citizen scientists' contributions is extremely helpful when covering large geographic scales that would be prohibitively expensive or technically challenging for a small team of researchers. Benefits of citizen science projects go beyond the valuable data collected by participants. Engaged citizen scientists who feel stewardship over their communities have the potential to become invested stakeholders and public advocates for environmental change in their communities (Shirk et al. 2012). Citizen scientists may also apply knowledge gained from their 
participation to their own local environment; for example, they may improve habitat or plant native species on their property (Ryan et al. 2001, Evans et al. 2005).

Research focused on citizen scientists' motivations and demographics has not experienced the same rapid growth as the use of citizen science in research projects (Edwards 2014, Jordan et al. 2015, Geoghegan et al. 2016). Additionally, much of the existing research on citizen scientists have focused on noncontributory projects; the motivations of participants of collaborative projects (e.g., Rotman et al. 2012), of online projects (e.g., Raddick et al. 2010), or of smartphone-based contributory projects (Land-Zandstra et al. 2016) may not be applicable to participants of standard contributory projects, though common motivations across studies include an interest in the subject, e.g., astronomy, an interest in science, and a desire to contribute to a scientific project. Among contributory projects, commitment lengths range from a few hours once a year, e.g., Christmas Bird Count, to across a season, e.g., Neighborhood NestWatch (Evans et al. 2005), making it difficult to compare among projects. Researchers working with citizen scientists must understand why and how people participate so that they can better recruit new participants, continue to engage skilled participants that may be able to mentor others, and retain trained participants over the long term for the continued success of citizen science projects.

Self-determination theory focuses on the study of internally driven intrinsic motivation, e.g., exploration, learning, and enjoyment, and externally driven extrinsic motivation, e.g., obligation, monetary gain, and status gain, and how they vary with changing circumstances (Ryan and Deci 2000, Gagné and Deci 2005). Intrinsic motivation, which is thought to fuel activities that are appealing in a novel, challenging, or aesthetic manner, is bolstered by the participant's perceived autonomy, competence at the activity, and sense of relatedness with other participants or the community (Ryan and Deci 2000). Activities that stifle autonomy, present overwhelming difficulty, or feature impersonal social interactions result in decreased intrinsic motivation (Ryan and Deci 2000). Understanding how participants feel in citizen science programs can help us determine how to encourage initiation and continued participation by promoting intrinsic motivation, leading to more fulfilling and productive experiences, and more engaged participants.

In addition to motivations, it is also important to understand how citizen science participation influences the use and development of scientific thinking, which has broad cultural implications that extend beyond the volunteer experience itself. Some citizen science projects assume that the act of participation is enough to improve knowledge and understanding, and provide no extraneous training in conservation. The Cornell Lab of Ornithology evaluated participants' learning to better facilitate education, and found an increase in scientific literacy and use of scientific thinking after participation (Bonney et al. 2009, 2016), though other studies have found no change in scientific understanding (Jordan et al. 2011). Regardless of extra training, participants in contributory projects typically increased their ecological knowledge during the project, resulting in varying degrees of behavioral impacts (Ryan et al. 2001, Jordan et al. 2011, Bonney et al. 2016). Perhaps more importantly, participation in citizen science projects is thought to create a personal and emotional connection to the research and to nature (Livingston 1981, Bell et al. 2008), improving "sense of place" and encouraging participants to be local stewards (Ryan et al. 2001, Shirk et al. 2012). Therefore, evaluating whether participation in citizen science activities is correlated with scientific literacy and environmentally conscious behavior may help us understand the extent to which citizen science programs may have cultural implications beyond the value of the data collected.

We conducted a survey of participants of the Manitoba Nocturnal Owl Survey (Duncan 2016) in order to (1) learn about participants' motivations to participate and what they gain from the experience, and (2) examine how participation in the project relates to attitudes toward science, specifically, perceived scientific literacy, scientific media consumption, and environmental and conservation concerns.

\section{METHODS}

\section{Manitoba Nocturnal Owl Survey}

The Manitoba Nocturnal Owl Survey (MNOS) is a 27-year-old ongoing citizen science project across Manitoba that trains participants to identify local nocturnal birds by sound and then instructs them on how and when to survey for birds on set routes. The primary goal of the survey is to provide an organized learning opportunity for volunteers to develop a personal relationship with owls and nature through participation (J. Duncan, MNOS founder, personal communication). Secondary survey goals include data collection on owl distribution, abundance, habitat associations, and trends. Dissemination of survey results include annual reports, public outreach, and presentations conducted by the survey coordinator. The survey was initiated to compliment traditional daytime breeding bird surveys, which underreport owl and nocturnal bird abundances.

The Manitoba Nocturnal Owl Survey requires a minimum commitment of one night per year during the owl survey period (late March to early April). Surveys were conducted between half an hour after local sunset and midnight. Prior to participation, participants were provided access to audio recordings of owl species found in the province, and were expected to familiarize themselves with owl identification. Participants typically conducted one route per night, but some conducted two consecutive surveys in one evening. Some participants did multiple routes per year.

From 1991 to 1999 , both passive listening and owl call playback were used to survey owls. From 2000 onward, the use of playback ceased and participants surveyed for owls by passive listening only (Duncan 2016). Participants drove along designated routes, and exited the vehicle to listen for owls at 10 stations $1.6 \mathrm{~km}$ apart for two minutes at each station. At each station, participants noted the presence of owl species heard or seen, including the number of owls, and their distance and direction from the observer. Participants also recorded ambient conditions during the survey on the provided data sheets, including environmental conditions and ambient noise (see http://www.naturenorth.com/summer/ creature/owl/owl_new/owl2005.html for full protocol and data sheets).

At the end of each annual survey, participants submitted their data to the survey coordinator, who compiled results and provided a summary report to participants and the general public on the project's web site (http://www.NatureNorth.com ; Duncan 2016). 
The data have also been shared with students and organizations for education and conservation research purposes and have been used in scientific publications (e.g., Duncan and Duncan 1997, Duncan et al. 2009).

\section{Questionnaire}

We designed and wrote an online questionnaire using Google Forms asking past participants of the Manitoba Nocturnal Owl Survey about their demographics, their motivations and participation behavior, and their experiences and opinions on scientific education, the environment, and wildlife conservation (see Appendix 1). We referred extensively to guidelines set by the Cornell Lab of Ornithology's User's Guide for Evaluating Learning Outcomes from Citizen Science (Phillips et al. 2014) when developing our questionnaire to ensure the highest level of clarity in both our intentions and in the wording of each question. We adapted and simplified their demographics questions ("Appendix G: Basic Demographic Questions"). We also reviewed the questions posed by other motivation studies (e.g., Campbell and Smith 2005).

The questionnaire consisted of 45 questions (Appendix 1), including some questions that were only seen by a relevant subset of respondents. Demographics questions were close-ended and multiple choice to maintain anonymity. Science and ecology questions were a combination of close-ended questions, including multiple choice and 5-point scale formats (e.g., level of concern about environmental issues, where 1 was "not at all" concerned, and 5 was "very" concerned), and open-ended questions. One of the science and ecology questions asked respondents to self-report their scientific literacy on a 5-point scale, allowing us to gauge their perception of their scientific understanding. Open-ended questions were either mandatory (e.g., "Have you participated in other scientific or ecological projects? List and describe") or optional open-ended questions for elaborating on close-ended answers. Motivation and participation behavior questions were a combination of close-ended questions, including multiple choice (e.g., "What originally motivated you to start volunteering?" had four choices and a write-in "other" option), and both mandatory and optional open-ended questions.

In November 2015, J. Duncan distributed by email the link to the questionnaire to all 255 past and current participants for whom we had active email addresses, out of the total of 900 known participants in the surveys. Email recipients of the surveys were invited to pass along the email with the questionnaire link to other participants. Respondents of the survey were also invited to participate in a raffle for a museum membership and bird guidebooks. The survey remained available online for 72 days. The data collected from this survey was both anonymous and confidential, and as such, may not be publically archived.

\section{Analyses}

We completed statistical analyses in $\mathrm{R}$ Core 3.1.2, with the package Hmisc: Harrell Miscellaneous (R Core Team 2015, Harrell 2016). We report demographic results with frequencies and percentages, and 5-point scale responses with means. Preliminary Shapiro-Wilk tests $(p<0.05)$ indicated that residuals were not normally distributed, therefore we calculated all motivational and behavioral correlations using nonparametric tests. We calculated the Spearman correlation $\left(r_{s}\right)$ for ordinal and continuous variables, and compared categorical variables using the Kruskal-Wallis one-way analysis of variance $\left(\chi^{2}\right)$. We coded responses to open-ended questions, such as specific environmental or conservation concerns cited by respondents, based on overarching themes.

\section{RESULTS}

\section{Demographics and scientific attitudes}

We received 69 responses in total, representing a maximum of $27 \%$ of those invited to complete the survey by email. Respondents were fairly evenly split by gender, with $48 \%$ identifying as female (see Table 1 for detailed demographics information). Most ( $88 \%$ ) respondents either identified their background as only European, or wrote in variations of "Canadian" or "American." Almost half of respondents reported they were at least 55 years old at the time of the questionnaire $(48 \%)$. A majority of respondents indicated that they had completed at least an Associate's Degree, College Diploma, or Bachelor's Degree (86\%). Birding ability, or the ability to identify bird species by sight or sound, was distributed fairly evenly from inexperienced to expert, with no single ability level dominating.

Table 1. Demographics of respondents in a questionnaire on participation behavior and attitudes toward science distributed to Manitoba Nocturnal Owl Survey participants during November 2015-January $2016(\mathrm{n}=69)$.

\begin{tabular}{|c|c|c|}
\hline \multicolumn{2}{|c|}{ Demographic } & \multirow[t]{2}{*}{$\%$} \\
\hline Gender & & \\
\hline & Male & 52 \\
\hline & Female & 48 \\
\hline \multicolumn{3}{|l|}{ Ethnicity } \\
\hline & European & 88 \\
\hline & First Nations, Métis, or Inuit & 7 \\
\hline & Other $^{\dagger}$ & 7 \\
\hline \multicolumn{3}{|l|}{ Age } \\
\hline & $\leq 24$ & 4 \\
\hline & $25-34$ & 19 \\
\hline & $35-44$ & 7 \\
\hline & $45-54$ & 22 \\
\hline & $55-64$ & 19 \\
\hline & $\geq 65$ & 29 \\
\hline \multicolumn{3}{|c|}{ Education } \\
\hline & High School & 4 \\
\hline & Some Post-secondary & 10 \\
\hline & Associate Degree & 9 \\
\hline & Bachelor Degree & 36 \\
\hline & Post-graduate Diploma & 1 \\
\hline & Post-graduate Degree & 25 \\
\hline & Doctorate & 15 \\
\hline \multicolumn{3}{|c|}{ Birding Ability (\# species recognized) } \\
\hline & Not birder & 13 \\
\hline & $<50$ species & 19 \\
\hline & $<100$ species & 19 \\
\hline & $<200$ species & 20 \\
\hline & $<400$ species & 10 \\
\hline & $\geq 400$ species & 19 \\
\hline
\end{tabular}

Refers to all participants who were not of full European background or of First Nations, Métis, or Inuit background. ${ }^{\sharp}$ Includes Masters and Medical degrees. 
Table 2. Nonmutually exclusive issues of environmental and conservation concern described by participants of the Manitoba Nocturnal Owl Survey in a questionnaire on participation behavior and scientific attitude distributed during November 2015-January 2016 $(\mathrm{n}=$ 56).

\begin{tabular}{|c|c|c|c|c|c|}
\hline Issue & Number & Percentage & Issue & Numbers & Percentage \\
\hline Habitat degradation/ loss/fragmentation & 38 & 67.9 & Industry-related & 8 & 14.3 \\
\hline Climate change and emissions & 29 & 51.8 & Invasive species & 8 & 14.3 \\
\hline Sustainability & 20 & 35.7 & Deforestation & 7 & 12.5 \\
\hline Water quality & 16 & 28.6 & Nature disconnect & 5 & 8.9 \\
\hline Government & 15 & 26.8 & Prairie-related & 5 & 8.9 \\
\hline Pollution & 12 & 21.4 & Hunting, poaching, and fishing & 4 & 7.1 \\
\hline Public education and perception & 12 & 21.4 & Lake Winnipeg-related & 4 & 7.1 \\
\hline Population decline and species at risk & 11 & 19.6 & Insufficient funding & 3 & 5.4 \\
\hline Development and urban sprawl & 9 & 16.1 & Northern Canada-related & 3 & 5.4 \\
\hline Ecosystem disruption and loss of key species & 9 & 16.1 & Oceans-related & 3 & 5.4 \\
\hline Management insufficiency or style & 9 & 16.1 & First Nations, Inuit, and Métis & 2 & 3.6 \\
\hline Wetlands and drainage & 9 & 16.1 & Aspen encroachment & 1 & 1.8 \\
\hline Agriculture & 8 & 14.3 & ATV usage & 1 & 1.8 \\
\hline Biodiversity loss & 8 & 14.3 & & & \\
\hline
\end{tabular}

Perceived scientific literacy was a mean of 4.2 on a 5 -point scale $(\mathrm{SD}=0.94)$. Most respondents $(70 \%)$ cited that their scientific literacy primarily came from formal sources, such as postsecondary level classes. Informal sources of scientific literacy included volunteering, recreation, and self-directed learning. Eight individuals $(12 \%)$ elaborated to say their literacy came equally from formal and informal sources. Individuals with formal scientific backgrounds had generally completed a higher level of education $\left(\chi^{2}=21.3, p<0.001\right)$, had higher perceived scientific literacy $\left(\chi^{2}=23.9, p<0.001\right)$, and more passive exposure to scientific media $\left(\chi^{2}=6.74, p=0.009\right)$. Perceived scientific literacy was positively correlated with passive $\left(r_{s}=0.34, p=0.004\right)$ and active $\left(r_{s}=0.33, p=0.006\right)$ exposure to scientific media. There were no other significant correlations between perceived scientific literacy or scientific background with science media exposure.

Respondents were generally concerned about both the environment (mean rating of $4.7, \mathrm{SD}=0.63$ ) and wildlife conservation (mean rating of $4.8, \mathrm{SD}=0.42$ ). Environmental and conservation concern were both positively correlated with education (environment: $r_{s}=0.32, p=0.008$; conservation: $r_{s}=$ $0.25, p=0.035)$. Environmental concern was positively correlated with passive $\left(r_{s}=0.27, p=0.025\right)$ but not active $\left(r_{s}=0.22, p=\right.$ 0.074 ) exposure to science media. Respondents were invited to list specific environmental and conservation concerns, and after combining all nonmutually exclusive concerns $(n=56)$, habitatrelated concerns were listed most frequently, by $68 \%$ of respondents (see Table 2). The next most common concerns were climate change $(52 \%)$, sustainability $(36 \%)$, water quality $(29 \%)$, and insufficient government oversight or concern $(27 \%)$. The questionnaire provided climate change, water pollution, and air pollution as examples of environmental issues in the question wording. Respondents also participated in a range of other citizen science or ecological projects. Most respondents $(88 \%)$ listed other projects they worked on, including other ornithological projects $(80 \%)$ and ecological or restoration projects $(13 \%)$. Christmas Bird Count (58\%), Breeding Bird Survey (48\%), and the Manitoba Breeding Bird Atlas (29\%) were the most common projects listed, with $71 \%$ of respondents having participated in at least one of those three, and $16 \%$ having done all three.
Respondents named 36 other projects they had participated in, including mammalogy, herpetology, and invertebrate projects.

\section{Participation behavior}

Over three-quarters of respondents (78\%) heard about the survey through word-of-mouth or active recruitment. Two-thirds of respondents were current participants $(68 \%)$. All first-time participants $(n=4)$ expressed the intent to participate again the following year, and excluding these first-time participants, one individual who had relocated out-of-province, and one individual with a technical issue, all remaining $(n=63)$ respondents had participated for at least two years. This suggests a response bias, such that individuals who participated in only a single year of MNOS, and thus may be less engaged by the experience, did not respond to our questionnaire. As such, our results must be interpreted with the caution that they are biased toward those participants who enjoyed the experience the most. Respondents had participated in the surveys for a median of 5 years and a mean of 7.9 years $(\mathrm{SD}=6.60)$, with a mean consistency, or percentage of years active since the beginning of their tenure, of $69 \%$ (SD $=$ $0.30)$. Seven respondents $(10 \%)$ had participated since the first year, and 12 respondents $(17 \%)$ volunteered with a $100 \%$ consistency rate. A third of respondents (32\%) reported traveling at least $100 \mathrm{~km}$ to their routes.

The majority of respondents $(86 \%)$ participated with companions, generally with friends $(66 \%)$ and family $(49 \%)$. Other survey companions included children $(8 \%)$, students $(7 \%)$, and coworkers $(2 \%)$. Three individuals $(5 \%)$ additionally reported that they preferred to survey with birders.

Years of participation was positively correlated with birding ability $\left(r_{s}=0.50, p<0.001\right)$ and age $\left(r_{s}=0.42, p<0.001\right)$. Those who surveyed alone participated for significantly more years (mean $=9.8$ years, $\mathrm{SD}=5.5)$ than those who surveyed socially $\left(\right.$ mean $=7.5$ years $\left.\mathrm{SD}=6.8 ; \chi^{2}=3.89, p=0.049\right)$. Women were significantly more consistent participants than men $\left(\right.$ mean $_{\text {women }}$ $=76 \%, \mathrm{SD}=0.29 ;$ mean $_{\text {men }}=63 \%, \mathrm{SD}=0.30 ; \chi^{2}=5.78, p=$ $0.016)$. There were no other statistically significant correlations between demographic variables or social participation preference with participation behavior. 


\section{Motivations}

When supplied with a list of four motivation types ("personal reasons," "professional reasons," "conservation concerns," "educational opportunity," or other; see Appendix 1), most respondents $(72 \%)$ selected "personal reasons" to describe their original motivation. Some respondents elaborated and provided specific reasons including social invitations, interest in birding, and a desire to be in nature (see Table 3). For example, respondent \#20 reported that they helped friends initially: "Birding friends had owl routes and I helped them and then acquired my own route."

Table 3. Motivations identified by participants of the Manitoba Nocturnal Owl Survey in a questionnaire on participation behavior and scientific attitude distributed during November 2015-January 2016 $(n=69)$. Some respondents identified multiple motivations, and respondents were given the option to elaborate on their motivations.

\begin{tabular}{lcl}
\hline \hline Motivation Category & Percentage & Examples \\
\hline Personal & 72 & Invitation from friend/family \\
& & Birding/recreational opportunity \\
& Helping friends \\
& Being in nature \\
& Seeing owls \\
& & Volunteer opportunity \\
Conservation & 42 & Protect owl habitat \\
& & Protect wildlife \\
Professional & 30 & N/A \\
Educational & 29 & Learn about owls \\
& & Participate through school \\
& & Educational recreation \\
\hline
\end{tabular}

Fewer respondents $(42 \%)$ listed conservation as an original motivation. Respondent \#60 said they "Wanted to do my part in the effort to learn about and protect owl habitat." "Professional reasons" was listed as a motivation by $30 \%$ of respondents. "Education opportunity" was identified by $29 \%$ of respondents as an original motivation. Most of these people listed "education opportunity" in conjunction with another motivation; only two respondents (3\%) listed "educational opportunity" alone.

A fifth of respondents $(20 \%)$ indicated that their motivations had changed over time. For example, five respondents began surveying for personal reasons but later were also motivated by conservation concerns. A few respondents indicated that their motivations shifted from professional to personal $(3 \%)$ or the reverse $(6 \%)$. There was no significant difference in number of years participated between those whose motivations had changed and those whose motivations remained the same.

\section{Benefits and personal consequences}

When asked in an open-ended format what they gained from their owl surveying experience, new or increased knowledge was most often described (75\%; see Fig. 1). Owl-related experiences and appreciation was the second-most commonly described (38\%), followed by nature- and outdoors-related experiences and appreciation (32\%). Interpersonal interactions and contributions to a conservation project were each described by $22 \%$ of respondents, followed by general enjoyment or "fun" (17\%) and a greater understanding or appreciation for surveying techniques and data collection $(17 \%)$.
Fig. 1. Common benefit categories identified by participants of the Manitoba Nocturnal Owl Survey in an open-ended question as part of questionnaire on participation behavior and scientific attitude distributed during November 2015-January $2016(n=69)$. Some respondents identified multiple benefits.

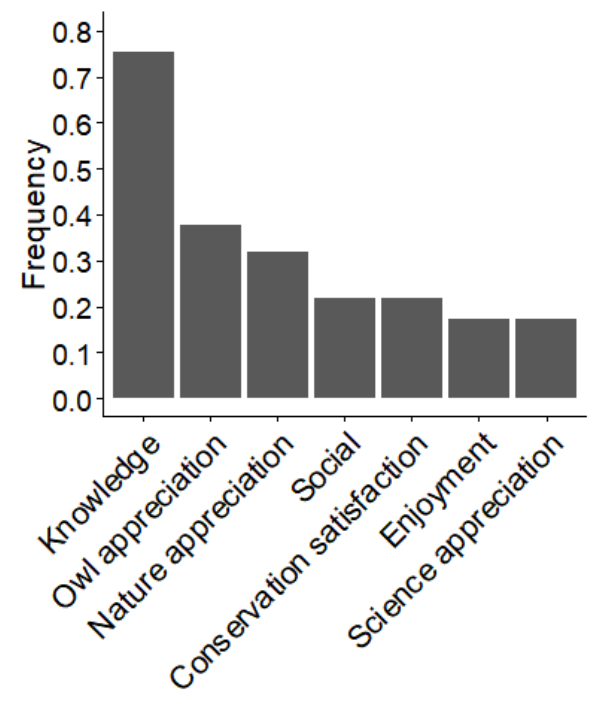

Benefits

Favorite moments $(n=45)$ optionally described by respondents often involved wildlife and nature experiences, including both owls $(62 \%)$ and other wildlife or nature experiences $(42 \%)$. Respondent \#9 shared, "One night I was standing on a quiet country road when a loud pack of coyotes stampeded a herd of deer along the road in front of me. This is a moment you never forget!" Other favorite moments arose through sharing the enjoyment of the activity with companions $(25 \%)$. Respondent \#16 said, "It's been especially rewarding these last few years as I've started to involved (sic) former students. It's great seeing their enthusiasm as we collect data."

\section{Reasons for leaving}

Moving, aging, and health concerns were the two most commonly cited reasons respondents said had or would cause them to stop volunteering (see Table A2.1 in Appendix 2 for full list of reasons). Among ex-participants $(n=22)$, moving from their routes or outof-province caused $41 \%$ to stop volunteering, and aging and health concerns caused 18\% to stop. Among current participants $(n=47)$, the pattern was reversed. Aging and health concerns were the most cited reason for potentially leaving the project $(47 \%)$, followed by moving $(17 \%)$. Social reasons also resulted in some individuals leaving the survey program; three individuals (14\%) had stopped participating because their regular survey companions were no longer available, and one current participant had cited losing their regular partner as a potential cause for leaving.

\section{Patterns in motivation}

Respondents who selected "professional reasons" were more likely to be younger than 45 years $\left(\chi^{2}=4.15, p=0.042\right)$, possess a formal scientific background $\left(\chi^{2}=6.14, p=0.013\right)$, and have 
completed at least a Bachelor's degree $\left(\chi^{2}=5.67, p=0.017\right)$. Respondents that selected conservation as a motivation were more likely to conduct the survey with others $\left(\chi^{2}=4.85, p=0.028\right)$. We found no other significant correlation between original motivations and demographic (student status, birder), behavioral (years participated), or science background (perceived scientific literacy, environmental concern, conservation concern) variables $(p>0.05)$.

\section{DISCUSSION}

Our results highlight some unique features of participants with the Manitoba Nocturnal Owl Survey, emphasizing the need for individual assessments of different citizen science programs based on natural history and population demographics relevant to each project. Overall, though, the importance of social recruitment for initiation, including general word-of-mouth recruitment and personal motivations such as personal invitations to participate, is likely to influence success of other volunteer programs as well. The interaction between experiencing nature and interpersonal bonding, including mentoring, suggests that a shift from marketing citizen science programs as educational opportunities to an opportunity to spend time volunteering in nature with friends and family might attract more or different types of volunteers, especially if project organizers target outdoor recreation groups or other environmental volunteer groups (Cooper et al. 2007). Participants are highly likely to gain ecological knowledge and insight through their experiences, although this was rarely a recognized motivation for respondents to start volunteering.

\section{Demographics and scientific attitudes}

Respondents were evenly split by gender, which is unusual as volunteers with ornithological projects (excluding those that take place at home, like FeederWatch) and nature-based volunteering in general are usually predominately men (Cooper and Smith 2010, Edwards 2014). There were no stated differences in birding ability between genders, unlike results of previous studies, which found that men often valued and possessed higher bird identification skills (Cooper and Smith 2010, Lee et al. 2015). Women participated more consistently over the years in which they volunteered, consistent with studies that found women volunteer more in general (Paik and Navarre-Jackson 2011, Edwards 2014). The high education level among respondents is generally consistent with education levels of respondents in other volunteer surveys (Paik and Navarre-Jackson 2011, Edwards 2014, Domroese and Johnson 2017), though the proportion of MNOS respondents aged 25 to 64 that held Bachelor's Degrees was double the proportion seen in the Canadian volunteering public (Turcotte 2015). The age of Manitoba Nocturnal Owl Survey respondents also exceeded that of the national average age of volunteers in Canada, as our proportion of $48 \%$ respondents aged 55 or older was much higher than the national proportion of $28 \%$ (Turcotte 2015). The low proportion of minorities participating is consistent with other studies of citizen science in North America (reviewed in Pandya 2012, Geoghegan et al. 2016, Domroese and Johnson 2017). Minorities, First Nations, Métis, and Inuit make up 30\% of Manitoba's population (Statistics Canada 2016), but only accounted for $12 \%$ of our respondents.

Perceived scientific literacy was positively correlated with passive and active exposure to scientific media, including active informal learning, consistent with previous studies (Miller 2004). We did not detect a correlation between either environmental concern or conservation concern and number of years or consistency of participation, consistent with past studies that have found minimal influence of environmental values on environmental action (McDougle et al. 2011). In our study, it is possible that this was because of a ceiling effect because all respondents demonstrated at least moderate environmental concern and action (through volunteering on the survey). Because the majority of respondents in our study indicated that they took part in multiple citizen science studies, future research could look for relationships between total amount of participation or commitment across citizen science projects and nature relatedness (Nisbet et al. 2009), scientific literacy, and concern for the environment and conservation.

\section{Barriers to participation}

The discrepancy in age between survey respondents and Canadian volunteers in general may be partially explained by two aspects of the survey. First, this project presents a unique barrier to participation because it requires a vehicle, likely preventing many high school-aged prospective volunteers from participating, an age group that typically makes up the largest proportion of volunteers in Canada (Turcotte 2015). Although not mentioned by our respondents, the cost of participation through associated transportation, i.e., fuel, costs presented a barrier in another ornithology project (Wolcott et al. 2008), and may deter underprivileged potential participants. Conversely, because the survey requires only the commitment of one night a year, participation in this survey may be more accessible in terms of time than other forms of volunteering. Longer time commitments are a common barrier to volunteering in Canada (McClintock 2004) and in other ornithology projects (Wolcott et al. 2008). The one-day time commitment required in the owl survey may have resulted in a lower volunteer drop-off rate in aging participants than seen in other programs. However, the aging population of this project's participants is still an important factor to consider in developing a strategy to maintain the Manitoba Nocturnal Owl Survey because a number of respondents had indicated that potential health and aging problems may prevent them from participating in the future, similar to another ornithology project with a similar age demographic (Wolcott et al. 2008). Aging and associated health issues, including hearing impairment, is a concern to ornithology citizen science projects in general because the heavy reliance on the ability to distinguish and identify sounds presents a common barrier to participation in these projects (Farmer et al. 2014).

Lack of awareness of opportunities is a common barrier to participation in environmental programs (Hobbs and White 2012), and this effect is compounded for certain groups within the community. Immigrants in Canada are more likely than Canadian-born individuals to face certain barriers to participation, often citing lack of knowledge or not being invited as reasons for not volunteering (McClintock 2004, Scott et al. 2006). Participation among minorities, including indigenous communities who may offer unique perspectives and recent immigrants who may not yet have formed a connection with Canadian nature, should be encouraged by reaching out directly to these communities (McClintock 2004, Winter et al. 2004). Project managers can make a concerted effort to reach minority 
communities, which may involve giving presentations or leaving informational materials at cultural community centers, places of worship, or in community newsletters (McClintock 2004), or distributing promotional materials in multiple languages (Winter et al. 2004). Additionally, recruiters should be mindful that individuals who come from a cultural background other than North American European may be motivated by different factors (Walker et al. 2001, Winter et al. 2004, Asah et al. 2014).

\section{Motivations and behaviors}

The opportunity to be out in nature was an important motivation for and benefit of participation, and interpersonal opportunities also had a large impact on respondents' choice to participate at every stage of the decision-making process. Personal reasons were the most commonly cited motivations, and were often elaborated as interpersonal reasons for volunteering, such as a chance to volunteer with friends. Over three-quarters of people heard about the project through word-of-mouth or active recruitment, and some individuals indicated that they participated on a friend's route before acquiring a survey route of their own. Recruitment by an organization or individual is possibly the most important means of acquiring participants for many programs, in both the Canadian volunteering context and in other citizen science projects (McClintock 2004, Paik and Navarre-Jackson 2011). Once recruited, the majority of people participated with others, and several favorite moments shared by respondents included references to experiences enjoyed with others. Loss of a surveying partner was also a common reason for why people stopped surveying, further highlighting the importance of companionship. We note that respondents' desire for a surveying partner may also reflect safety and security concerns, particularly given that MNOS surveys are done at night. However, individuals who participated socially were also more likely to participate intermittently, perhaps because their participation depended on availability of survey partners. We found no correlation between motivation and participation frequency, consistent with previous research that found motivations of environmental volunteers were not correlated with their participation frequency or duration (Ryan et al. 2001).

Nature-based and interpersonal motivations also interacted with one another (see also Bell et al. 2008, Bonney et al. 2016). Many respondents described enjoying sharing their experience of nature with others, both when describing gains and favorite memories. Two-thirds of respondents who expressed interpersonal bonding as a gain also expressed an appreciation of owls or nature, often intertwining interpersonal and nature-based benefits; for example, respondent \#16 said "I now get the opportunity to share that knowledge and the moments of wonder when you an encounter an owl with former students who are upcoming ecologists/scientists."

Among favorite memories, $89 \%$ of those who described an interpersonal bonding moment also expressed enjoying being around owls or in nature; for example, two individuals described memories of hearing owls with a daughter or a niece. Mentoring, or social learning, is an important facet of the nature-social interaction (Bell et al. 2008). Several respondents described their enjoyment in sharing their knowledge and this experience with students or younger people, while other respondents described how they preferred to conduct the survey with more knowledgeable birders. Overall, these stories suggest that despite respondents' overall high level of concern for wildlife conservation, the majority of respondents were participating primarily because of the enjoyment of the survey. This positive interaction is consistent with self-determination theory, as intrinsic motivation, originally arising from the novelty of the project combined with intrinsic or aesthetic enjoyment of nature, is enhanced by a sense of community and enjoyment of companions, as well as the feeling of increased competence as the mentor or in the presence of a mentor (Ryan and Deci 2000). The primary motivation for most respondents appeared to be intrinsic enjoyment, rather than a sense of obligation or need to contribute, i.e., extrinsic motivation (Ryan and Deci 2000) because the inherently extrinsic professional and conservation motivations were less commonly cited than personal motivations, which were often intrinsic.

Despite the fact that citizen science projects are often marketed as an informal science educational opportunity, only two respondents were motivated to participate purely for educational reasons. In contrast, the most common gain respondents identified was knowledge. This is contrary to studies on other types of volunteering, where knowledge gain is a less common outcome of the experience (Edwards 2014). This highlights a key difference between citizen science projects compared with other volunteer experiences, as an emphasis on learning new skills is part of citizen science participation. An important next step may be to compare motivations of citizen scientists with those of other volunteers. Perhaps volunteers in general are motivated in part by commitment to a cause (a form of extrinsic motivation; Gagné and Deci 2005), but citizen scientists in contributory projects derive more intrinsic enjoyment than other types of volunteers. The majority of respondents also took part in other citizen science or ecological projects. Many respondents listed the same several projects, specifically the Christmas Bird Count, Breeding Bird Survey, and the Manitoba Breeding Bird Atlas, suggesting a possible circular recruiting social network of citizen ornithologists in Manitoba. Future research could explore how often citizen scientists volunteer outside of citizen science projects, and assess differences in motivation between citizen science and their other volunteer commitments (e.g., using criteria in Ryan et al. 2001, Domroese and Johnson 2017).

Although the opportunity for learning did not explain recruitment, respondents still acknowledged and appreciated that they learned something new while participating. This disparity between the small number of respondents motivated by educational opportunity and the large number of respondents who benefited from knowledge gain might be attributed to the self-reported nature of motivation in our questionnaire. It is important to note that self-reported results may be subject to selfdeception, the unconscious bias people apply toward maintaining a certain perception of themselves (Trivers 1991, Hirschfeld et al. 2008). Similarly, surveys of British citizen scientists and environmental volunteers also found that although few respondents identified the desire to learn something new or develop new skills as their primary motivation, learning or developing new skills was a common benefit among environmental volunteers (Hobbs and White 2012, Geoghegan et 
al. 2016). Consistent with our results, these studies also identified wildlife and nature-related benefits as among the most common benefits (Hobbs and White 2012, Geoghegan et al. 2016). However, opportunity for learning was a popular motivation in two local American citizen science projects with similarly welleducated respondents: the Neighborhood Nestwatch project (Evans et al. 2005), and the Great Pollinator Project (Domroese and Johnson 2017). Unlike the Manitoba Nocturnal Owl Survey, these projects typically took place at one's residence over the course of a season, and organizers provided in-person support via visits or orientation sessions for participants. We also note that discrepancies in wording among surveys can make their results difficult to compare; nonetheless, it seems clear that interpersonal motivations were stronger than educational ones in our study.

As participants' initial motivations are met and as they become established in the project, their motivations may evolve (e.g., Ordubegian and Eagles 1990, Ryan et al. 2001, Geoghegan et al. 2016). A subset of respondents indicated that their motivations had changed over time. Some respondents who were initially motivated by personal reasons were later motivated by conservation concerns (see also Geoghegan et al. 2016). Shifting from career-related motivations to personal motivations has also been documented (Geoghegan et al. 2016), indicating a possible shift from extrinsic, goal-based motivation to intrinsic, recreational motivation. In our study, several respondents also developed professional motivations for participating over time, which we have not seen documented elsewhere. This shift may indicate interest to pursue science professionally, perhaps inspired by citizen science participation. This suggests that participants may have developed or deepened their personal relationships with nature through citizen science participation (Livingston 1981, Bell et al. 2008), fulfilling the primary objective of the MNOS.

Because the loss of original motivations and benefits can result in cessation of the volunteer activity (Ordubegian and Eagles 1990), researchers should provide opportunities to address longterm participants' evolving motivations (Ryan et al. 2001). For example, programs may benefit from incorporating a mentorship structure to provide social and learning benefits (Ryan et al. 2001), especially as greater activity-based knowledge correlates with increased social integration within and greater commitment to an organization (Gahwiler and Havitz 1998), bolstering intrinsic motivation under self-determination theory (Ryan and Deci 2000). Organizers could add a program whereby experienced participants accompany first-time participants and provide hands-on training, helping the novice learn about owl identification and habitat while providing the experienced individual with another meaningful way to contribute. This is particularly important because experienced individuals may be more motivated by social interactions than beginners (Ewert et al. 2013), and participants with social motivations may be more committed to participation (Ryan et al. 2001). Studies on sport and leisure volunteering have also found that developing social bonds with other participants promotes attachment to the activity (Snelgrove et al. 2013), so providing social opportunities is likely to be particularly beneficial to participant retention (Bell et al. 2008, Asah et al. 2014, Geoghegan et al. 2016). End-of-season data presentation and social events (e.g., Domroese and Johnson
2017) may help participants feel like part of larger community, but may be less feasible in projects like the MNOS where participants are dispersed geographically. An alternative may be holding smaller celebratory gatherings in a few centralized communities across the province. Additionally, a private forum for participants within which participants can ask questions of researchers or the community at large (e.g., Raddick et al. 2010) may serve as a venue for engaging with other like-minded participants across the province (Domroese and Johnson 2017), as well as providing a learning opportunity. Overall, program designers may benefit from promoting the citizen science experience beyond the data collection process (e.g., "being in nature," "participating with friends," "a novel birding experience") in addition to emphasizing the importance of the work. Future research should further explore interpersonal dimensions of citizen science participation, perhaps examining the role of social networks for recruitment and the specific benefits of informal mentorships in citizen science projects.

\section{CONCLUSION}

Our results demonstrate the importance of taking personal motivations, including interpersonal experiences, into account when developing new projects, recruiting volunteers, and developing retention strategies for ongoing projects. Presenting citizen science projects as educational opportunities is not enough to attract participants; program developers need to appreciate that motivations are usually experiential, interpersonal, recreation, or conservation-related. Advertising directly to a wide variety of different communities, including indigenous communities, outdoor recreation groups, and postsecondary student clubs may help reach out to more diverse audiences within frameworks that implicitly integrate and benefit from interpersonal and mentor-type interactions. In addition, reaching out to immigrant communities may provide a unique opportunity for newcomers to form relationships with Canadian nature. However, program designers must concurrently consider the costs and benefits of attracting possibly shorter-term participants when developing recruiting strategies. If increasing exposure of the public to wildlife is a priority, engaging large numbers of new participants might be emphasized. However, if volunteer retention is necessary for program success, then a strategy that attracts participants of a diverse demographic mix, and includes a mentorship component for returning volunteers, may be most beneficial. Ultimately, organizers must always keep in mind their specific project goals and protocols when designing recruitment strategies to attract suitable and lasting participants.

Responses to this article can be read online at: http://www.ace-eco.org/issues/responses.php/1265

\section{Acknowledgments:}

We would like to thank all the participants of the Manitoba Nocturnal Owl Survey who took the time to answer our questionnaire and share their experiences with us. We would like to acknowledge Manitoba Sustainable Development for providing funding in support of our study through the Alice Chambers- 
Hyacinth Colomb Assistantship Program. Finally, we thank Dr. Iain Davidson-Hunt for his help and feedback.

\section{LITERATURE CITED}

Asah, S. T., M. M. Lenentine, and D. J. Blahna. 2014. Benefits of urban landscape eco-volunteerism: mixed methods segmentation analysis and implications for volunteer retention. Landscape and Urban Planning 123:108-113. http://dx.doi. org/10.1016/j.landurbplan.2013.12.011

Bell, S., M. Marzano, J. Cent, H. Kobierska, D. Podjed, D. Vandzinskaite, H. Reinert, A. Armaitiene, M. GrodzińskaJurczak, and R. Muršič. 2008. What counts? Volunteers and their organisations in the recording and monitoring of biodiversity. Biodiversity and Conservation 17(14):3443-3454. http://dx.doi. org/10.1007/s10531-008-9357-9

Bonney, R., C. B. Cooper, J. Dickinson, S. Kelling, T. Phillips, K. V. Rosenberg, and J. Shirk. 2009. Citizen science: a developing tool for expanding scientific knowledge and scientific literacy. BioScience 59(11):977-984. http://dx.doi.org/10.1525/bio.2009.59.11.9

Bonney, R., T. B. Philips, H. L. Ballard, and J. W. Enck. 2016. Can citizen science enhance public understanding of science? Public Understanding of Science 25(1):2-16. http://dx.doi. org/10.1177/0963662515607406

Campbell, L., and C. Smith. 2005. Volunteering for sea turtles? Characteristics and motives of volunteers working with the Caribbean Conservation Corporation in Tortuguero, Costa Rica. Mast 3(2):169-193

Cooper, C. B., J. Dickinson, T. Phillips, and R. Bonney. 2007. Citizen science as a tool for conservation in residential ecosystems. Ecology and Society 12(2):11. http://dx.doi. org/10.5751/ES-02197-120211

Cooper, C., and J. Smith. 2010. Gender patterns in bird-related recreation in the USA and UK. Ecology and Society 15(4):4. http://dx.doi.org/10.5751/ES-03603-150404

Domroese, M. C., and E. A. Johnson. 2017. Why watch bees? Motivations of citizen science volunteers in the Great Pollinator Project. Biological Conservation 208:40-47. http://dx.doi. org/10.1016/j.biocon.2016.08.020

Duncan, J. 2016. Manitoba nocturnal owl survey - 2015 annual report. NatureNorth.com. [online] URL: http://www.naturenorth. com/summer/creature/owl/owl_new/1\%20-\%202015\%20Manitoba's $\%$ 20Owl\%20Survey\%20Annual\%20Report\%20-\%20Final.pdf

Duncan, J. R., and P. A. Duncan. 1997. Increase in distribution records of owl species in Manitoba based on a volunteer nocturnal survey using Boreal Owl (Aegolius funereus) and Great Gray Owl (Strix nebulosa) playback. Pages 519-524 in J. R. Duncan, D. H. Johnson, and T. H. Nicholls, editors. Biology and conservation of owls of the Northern Hemisphere: second international symposium. General Technical Report NC-190, U. S. Forest Service, St. Paul, Minnesota, USA.

Duncan, J. R., S. R. Swengel, and A. B. Swengel. 2009. Correlations of Northern Saw-whet Owl Aegolius acadicus calling indices from surveys in southern Wisconsin, USA, with owl and small mammal surveys in Manitoba, Canada, 1986-2006. Ardea 97(4):489-496. http://dx.doi.org/10.5253/078.097.0413

Edwards, R. 2014. The 'citizens' in citizen science projects: educational and conceptual issues. International Journal of Science Education, Part B 4(4):376-391. http://dx.doi. org/10.1080/21548455.2014.953228

Evans, C., E. Abrams, R. Reitsma, K. Roux, L. Salmonsen, and P. P. Marra. 2005. The neighborhood nestwatch program: participant outcomes of a citizen-science ecological research project. Conservation Biology 19(3):589-594. http://dx.doi. org/10.1111/j.1523-1739.2005.00s01.x

Ewert, A., K. Gilbertson, Y. Luo, and A. Voight. 2013. Beyond "because it's there": motivations for pursing adventure recreational activities. Journal of Leisure Research 45(1):91-111. http://dx.doi.org/10.18666/j1r-2013-v45-i1-2944

Farmer, R. G., M. L. Leonard, J. E. Mills Flemming, and S. C. Anderson. 2014. Observer aging and long-term avian study data quality. Ecology and Evolution 4(12):2563-2576. http://dx.doi. org/10.1002/ece3.1101

Gagné, M., and E. L. Deci. 2005. Self-determination theory and work motivation. Journal of Organizational Behavior 26 (4):331-362. http://dx.doi.org/10.1002/job.322

Gahwiler, P., and M. E. Havitz. 1998. Toward a relational understanding of leisure social worlds, involvement, psychological commitment, and behavioral loyalty. Leisure Sciences 20:1-23. http://dx.doi.org/10.1080/01490409809512262

Geoghegan, H., A. Dyke, R. Pateman, S. West, and G. Everett. 2016. Understanding motivations for citizen science. Final report on behalf of UK Environmental Observation Framework, Wallingford, UK. [online] URL: http://www.ukeof.org.uk/ resources/citizen-science-resources/MotivationsforCSREPORTFINALMay2016.pdf

Harrell, F. E., Jr. 2016. Hmisc: Harrell Miscellaneous. The Comprehensive R Archive Network. [online] URL: https://cran. r-project.org/web/packages/Hmisc/index.html

Hirschfeld, R. R., C. H. Thomas, and D. B. McNatt. 2008. Implications of self-deception for self-reported intrinsic and extrinsic motivational dispositions and actual learning performance: a higher order structural model. Educational and Psychological Measurement 68(1):154-173. http://dx.doi. org/10.1177/0013164406299129

Hobbs, S. J., and P. C. L. White. 2012. Motivations and barriers in relation to community participation in biodiversity recording. Journal for Nature Conservation 20:364-373. http://dx.doi. org/10.1016/j.jnc.2012.08.002

Jordan, R., A. Crall, S. Gray, T. Phillips, and D. Mellor. 2015. Citizen science as a distinct field of inquiry. BioScience 65 (2):208-211. http://dx.doi.org/10.1093/biosci/biu217

Jordan, R. C., S. A. Gray, D. V. Howe, W. R. Brooks, and J. G. Ehrenfeld. 2011. Knowledge gain and behavioral change in citizen-science programs. Conservation Biology 25(6):1148-1154. http://dx.doi.org/10.1111/j.1523-1739.2011.01745.x 
Land-Zandstra, A. M., J. L. A. Devilee, F. Snik, F. Buurmeijer, and J. M. van den Broek. 2016. Citizen science on a smartphone: participants' motivations and learning. Public Understanding of Science 25(1):45-60. http://dx.doi.org/10.1177/0963662515602406

Lee, S., K. McMahan, and D. Scott. 2015. The gendered nature of serious birdwatching. Human Dimensions of Wildlife 20 (1):47-64. http://dx.doi.org/10.1080/10871209.2015.956375

Livingston, J. 1981. The fallacy of wildlife conservation. McLellan and Stewart, Toronto, Ontario, Canada.

McClintock, N. 2004. Understanding Canadian volunteers: using the national survey of giving, volunteering and participating to build your volunteer program. Canadian Centre for Philathropy, Toronto, Ontario, Canada. [online] URL: http://www. imaginecanada.ca/sites/default/files/www/en/giving/reports/ understanding_volunteers.pdf

McDougle, L. M., I. Greenspan, and F. Handy. 2011. Generation green: understanding the motivations and mechanisms influencing young adults' environmental volunteering. International Journal of Nonprofit and Voluntary Sector Marketing 16:325-341. http://dx.doi.org/10.1002/nvsm.431

Miller, J. D. 2004. Public understanding of, and attitudes toward, scientific research: what we know and what we need to know. Public Understanding of Science 13(3):273-294. http://dx.doi. org/10.1177/0963662504044908

Nisbet, E. K., J. M. Zelenski, and S. A. Murphy. 2009. The nature relatedness scale: linking individuals' connection with nature to environmental concern and behavior. Environment and Behavior 41(5):715-740. http://dx.doi.org/10.1177/0013916508318748

Ordubegian, L. N., and P. F. J. Eagles. 1990. An analysis of the motivations of volunteers in a short term environmental project. Pages 131-134 in B. Smale, editor. Leisure challenges: bridging people, resources, and policy into play. Proceedings of the Sixth Canadian Congress on Leisure Research, Ontario Research Council on Leisure, University of Waterloo, Waterloo, Ontario, Canada.

Paik, A., and L. Navarre-Jackson. 2011. Social networks, recruitment, and volunteering: are social capital effects conditional on recruitment? Nonprofit and Voluntary Sector Quarterly 40(3):476-496. http://dx.doi.org/10.1177/0899764009354647

Pandya, R. E. 2012. A framework for engaging diverse communities in citizen science in the US. Frontiers in Ecology and the Environment 10(6):314-317. http://dx.doi.org/10.1890/120007

Phillips, T., M. Ferguson, M. Minarchek, N. Porticella, and R. Bonney. 2014. User's guide for evaluating learning outcomes from citizen science. Cornell Lab of Ornithology, Ithica, New York, USA.

R Core Team. 2015. R: a language and environment for statistical computing. $\mathrm{R}$ Foundation for Statistical Computing. Vienna, Austria. [online] URL: http://www.R-project.org

Raddick, M. J., G. Bracey, P. L. Gay, C. J. Lintott, P. Murray, K. Schawinski, A. S. Szalay, and J. Vandenberg. 2010. Galaxy zoo: exploring the motivations of citizen science volunteers.
Astronomy Education Review 9(1). http://dx.doi.org/10.3847/ AER2009036

Rotman, D., J. Preece, J. Hammock, K. Procita, D. Hansen, C. Parr, D. Lewis, and D. Jacobs. 2012. Dynamic changes in motivation in collaborative citizen-science projects. Proceedings of the ACM 2012 Conference on Computer Supported Cooperative Work. ACM, New York, New York, USA. http://dx.doi. org/10.1145/2145204.2145238

Ryan, R. M., and E. L. Deci. 2000. Self-determination theory and the facilitation of intrinsic motivation, social development, and well-being. American Psychologist 55(1):68-78. http://dx.doi. org/10.1037/0003-066X.55.1.68

Ryan, R. L., R. Kaplan, and R. E. Grese. 2001. Predicting volunteer commitment in environmental stewardship programmes. Journal of Evironmental Planning and Management 44(5):629-648. http://dx.doi.org/10.1080/09640560120079948

Scott, K., K. Selbee, and P. Reed. 2006. Making connections: social and civic engagement among Canadian immigrants. Canadian Council on Social Development, Kanata, Ontario, Canada. [online] URL: https://volunteer.ca/vdemo/EngagingVolunteers_DOCS/ making-connections-social-and-civic-engagement-among-canadianimmigrants.pdf

Shirk, J. L., H. L. Ballard, C. C. Wilderman, T. Phillips, A. Wiggins, R. Jordan, E. McCallie, M. Minarchek, B. V. Lewenstein, M. E. Krasny, and R. Bonney. 2012. Public participation in scientific research: a framework for deliberate design. Ecology and Society 17(2):29. http://dx.doi.org/10.5751/ ES-04705-170229

Snelgrove, R., L. Wood, and M. E. Havitz. 2013. Developing personal attachment to a physically active charity event. International Journal of Nonprofit and Voluntary Sector Marketing 18:133-140. http://dx.doi.org/10.1002/nvsm.1464

Statistics Canada. 2016. Population and dwelling count highlight tables, 2011 census. Statistics Canada, Ottawa, Ontario, Canada. [online] URL: http://www12.statcan.gc.ca/census-recensement/2011/ dp-pd/hlt-fst/pd-pl/index-eng.cfm

Trivers, R. 1991. Deceit and self-deception: the relationship between communication and consciousness. Pages 175-191 in M. Robinson and L. Tiger, editors. Man and beast revisited. Smithsonian Institutional Press, Washington, D.C., USA.

Turcotte, M. 2015. Spotlight on Canadians: results from the general social survey. Volunteering and charitable giving in Canada. Statistics Canada, Ottawa, Ontario, Canada. [online] URL: http://www.statcan.gc.ca/pub/89-652-x/89-652-x2015001-eng.pdf

Walker, G. J., J. Deng, and R. B. Dieser. 2001. Ethnicity, acculturation, self-construal, and motivations for outdoor recreation. Leisure Sciences 23(4):263-283. http://dx.doi. org/10.1080/01490400152809115

Winter, P. L., W. C. Jeong, and G. C. Godbey. 2004. Outdoor recreation among Asian Americans: a case study of San Francisco Bay Area Residents. Journal of Park and Recreation Administration 22(3):114-136. 
Avian Conservation and Ecology 13(2): 9 http://www.ace-eco.org/vol13/iss2/art9/

Wolcott, I., D. Ingwersen, M. A. Weston, and C. Tzaros. 2008. Sustainability of a long-term volunteer-based bird monitoring program: recruitment, retention and attrition. Australian Journal on Volunteering 13(1):48-53. 


\section{Appendix 1.}

List of questionnaire questions provided to participants of the Manitoba Nocturnal Owl Survey citizen science project as part of a study on their motivations and scientific attitudes. Original questionnaire was distributed online using Google Forms, an interactive browser-based survey software.

Questions indicated by a * were only seen by a subset of respondents based on previous responses.

\section{$\underline{\text { Demographics }}$}

This section aims to get an idea of the cross-section of Manitoba Nocturnal Owl Survey volunteers. Who is the average volunteer?

How old are you?

○ 24 or under

○ $25-34$

○ $35-44$

○ $45-54$

○ $55-64$

○ $65+$

What is your gender?
- Male
- Female
O Other

What is your background? (Check all that apply.)

$\square \quad$ European

$\square \quad$ First Nations, Inuit, or Métis

$\square$ East Asian

$\square$ South Asian

$\square \quad$ Middle Eastern

$\square$ African

$\square$ Other:

What is the highest level of education you have completed?

- Did not complete high school

- High school graduate 
- Some post-secondary

- Associate's Degree or College Diploma

- Bachelor's Degree

- Master's Degree

- Doctorate

- Medical school

- Law school

o Other:

Are you currently a student or do you plan on further education?

- Yes, currently a student

- Yes, planning on further education

- No, neither

If you answered yes to the previous question, what level of education are you currently completing, or planning on completing?*

○ High school

- Associate's Degree or College Diploma

- Bachelor's Degree

- Master's Degree

- Doctorate

- Medical school

- Law school

o Other:

Do you have a post-secondary degree in natural sciences, environmental resources, or a related field?*

○ Yes

o No

If you answered yes to the previous question, what field is your degree in?*

Are or were you employed in the natural sciences or natural resources sectors?*

○ Yes

○ No 
If you answered yes to the previous question, who is or was your employer? (If retired, check off previous employer as well as retired.)*

$\square \quad$ Federal government

Other government

$\square$ University

$\square \quad$ Other educational institute

$\square$ Consulting firm

$\square \quad$ Non-governmental organization

$\square$ Retired

$\square$ Other:

\section{$\underline{\text { Science and Ecology }}$}

This section asks volunteers first about their scientific background and secondly about their opinions on science, ecology, and the environment. For the purpose of this questionnaire, "science" refers to the natural sciences, including biology, physics, chemistry, earth sciences, and medicine.

How often do you read or hear about science in the media? (For example: in the newspaper, on the radio, on television, online.)

- Daily

○ Multiple times a week

- Weekly

○ Bi-weekly

○ Monthly

$\bigcirc$ Less than once a month

How often do you deliberately try to learn more about science, either from established knowledge or science news? (For example: in science magazines, documentaries, science podcasts, science blogs, science videos.)

- Daily

- Multiple times a week

○ Weekly

○ Bi-weekly

○ Monthly

$\circ$ Less than once a month

How would you describe your scientific literacy? (Scientific literacy, at its simplest, is the ability of a person to understand scientific concepts and processes enough to meaningfully make personal decisions and engage in discussion and debate about science and technology. For a longer explanation, see http://www.literacynet.org/science/scientificliteracy.html) 
Poor 12345 Strong

How did you primarily acquire your scientific literacy?

- Formally (eg. classes or courses in college or university)

Informally (eg. self-taught, through recreation, volunteering, or personal reading)

- Combination

If you would like to expand on how you acquired your scientific literacy, please do so below.

How scientifically literate do you think the general Canadian public is?

Not literate enough 12345 Very literate

Are you concerned about wildlife and/or habitat conservation?

Not at all 12345 Very concerned

If wildlife or habitat conservation is a concern for you, what are your specific concerns?

Are you concerned about the declining state of the environment? (For example: global climate change, water pollution, or air pollution.)

Not at all 12345 Very concerned

If the declining state of the environment is a concern for you, what are your specific concerns?

Have you participated in other scientific or ecological projects? List and describe. (For example: Breeding Bird Survey, Christmas Bird Count, Project NestWatch, restoration projects, bird banding, Galaxy Zoo.)

Do you consider yourself a birder? How many birds can you identify by sight or sound?

○ No, I am not a birder

- Yes, I can identify $<50$ birds

- Yes, I can identify $<100$ birds

- Yes, I can identify $<200$ birds

$\circ$ Yes, I can identify $<400$ birds 
○ Yes, I can identify over 400 birds

Do you have any other wildlife experiences or interests? List and describe.

\section{Manitoba Nocturnal Owl Survey Experience}

This section asks about your experiences volunteering with the Manitoba Nocturnal Owl Survey, from how you were recruited to why you stopped (or would consider stopping) volunteering. How did you first hear about the Manitoba Nocturnal Owl Survey? (If more than one is applicable, check both.)

$\square$ Actively recruited

$\square$ Word-of-mouth

$\square \quad$ Manitoba Conservation and Water Stewardship presentation/meeting

$\square \quad$ Manitoba Hydro flier

$\square \quad$ Press release

$\square \quad$ Manitoba Government website

$\square \quad$ Bird studies Canada website

$\square \quad$ NatureNorth website

$\square$ Other:

What originally motivated you start volunteering? (Check all that apply.)

$\square$ Personal reasons

$\square$ Professional reasons

$\square$ Conservation concerns

$\square \quad$ Educational opportunity

$\square$ Other:

If you wish you explain your original motivations in more detail, please do so here.

Have your motivations changed since you started volunteering?

- Yes

o No

If you answered yes to the above, what are your motivations now? (Check all that apply.)* 
$\square \quad$ Personal reasons

$\square \quad$ Professional reasons

$\square$ Conservation concerns

$\square \quad$ Educational opportunity

$\square$ Other:

If you wish you explain your new motivations in more detail, please do so here.*

How many years have you participated with the Manitoba Nocturnal Owl Survey?

Which year did you begin volunteering?

Are you planning on volunteering in $2016 ?$

○ Yes

○ No

As a repeat volunteer, what has or may cause you to not volunteer in certain years?*

Do you typically conduct the survey alone or with others?

○ Alone

- With others

If you answered "with others" to the above question, who do you typically conduct your surveys with? (Check all that apply.)*

$\square \quad$ Family members

$\square \quad$ Children under 16

$\square \quad$ Friends

$\square$ Other:

How many routes have you covered in total? 
What do you feel you gained from your experiences volunteering with Manitoba Nocturnal Owl Survey?

Approximately how far is/are your route(s) from your residence (or cabin), in kilometers? (Use the starting point of your route for this distance. List multiple distances is you cover multiple routes.)

Do you read the Annual Report on the survey findings? What do you like about it, and is there anything else you would like to see in it?

If you would like to share one of your favourite moments or experiences of volunteering with the Manitoba Nocturnal Owl Survey, please do so below!

If you have any other comments, clarifications, or feedback you wish to share, please do so in the space below.

Thank you for participating in this survey. 


\section{Appendix 2.}

Table A2.1. Actual reasons cited by ex-participants $(n=22)$ and potential reasons cited by current participants $(n=47)$ for leaving the Manitoba Nocturnal Owl Survey in a questionnaire on participation behavior and scientific attitude distributed during November 2015 - January 2016. Some respondents listed multiple reasons.

\begin{tabular}{lllll}
\hline Reason & $\begin{array}{l}\text { Actual } \\
\text { Number }\end{array}$ & Percentage & $\begin{array}{l}\text { Potential } \\
\text { Number }\end{array}$ & Percentage \\
\hline Relocation & 9 & 40.9 & 8 & 17.0 \\
Health and aging & 4 & 18.2 & 22 & 46.8 \\
Route problems & 3 & 13.6 & 3 & 6.4 \\
Interpersonal & 3 & 13.6 & 1 & 2.1 \\
Lost interest & 3 & 13.6 & 0 & 0.0 \\
Survey problems & 2 & 9.1 & 6 & 12.8 \\
Time commitment & 2 & 9.1 & 4 & 8.5 \\
Not hearing owls & 2 & 9.1 & 3 & 6.4 \\
Transportation & 1 & 4.5 & 2 & 4.3 \\
\hline
\end{tabular}

